\title{
Buprenorphine-Induced Changes in Mu-Opioid Receptor Availability in Male Heroin-Dependent Volunteers: A Preliminary Study
}

Jon-Kar Zubieta, M.D., Ph.D., Mark K. Greenwald, Ph.D., Umberto Lombardi, M.D., James H. Woods, Ph.D., Michael R. Kilbourn, Ph.D., Douglas M. Jewett, Robert A. Koeppe, Ph.D., Charles R. Schuster, Ph.D., and Chris-Ellyn Johanson, Ph.D.

A principle of opioid pharmacotherapy is that high medication doses should occupy fractionally more opioid receptors that mediate heroin effects. In this preliminary study we examined in vivo $\mu$ opioid receptor ( $\mu O R)$ binding in three healthy opioid-dependent volunteers during maintenance on 2 and $16 \mathrm{mg}$ sublingual buprenorphine (BUP) liquid, and after detoxification $(0 \mathrm{mg})$ under double-blind, placebo-controlled conditions, and once in matched controls. Binding measures were obtained with the $\mu O R$-selective radioligand $\left[{ }^{11} C\right]$ carfentanil $(C F N)$ and PET 4 hrs after BUP administration. BUP induced dose- dependent reductions in $\mu$ OR availability, 36-50\% at $2 \mathrm{mg}$ and $79-95 \%$ at $16 \mathrm{mg}$ relative to placebo. Heroin abusers also had greater $\mu O R$ binding potential in the inferofrontal cortex and anterior cingulate regions during placebo, compared to matched controls. Further studies are warranted to examine the relationship of $\mu \mathrm{OR}$ availability with BUP therapeutic actions, and the clinical implications of increased $\mu O R$ binding during withdrawal.

[Neuropsychopharmacology 23:326-334, 2000] (C) 2000 American College of Neuropsychopharmacology. Published by Elsevier Science Inc. All rights reserved.
KEY WORDS: Buprenorphine; Positron emission tomography; Opiates; Opiate dependence; $\mathrm{Mu}$ opioid receptors; Carfentanil

Medications for the treatment of substance abuse may be developed for a variety of purposes (e.g., ameliorate

From the Mental Health Research Institute and Departments of Psychiatry, Internal Medicine (Division of Nuclear Medicine) (MRK, DMJ, RAK), and Neurosciences (J-KZ, UL, MRK, DMJ) and Department of Pharmacology (JHW), University of Michigan, Ann Arbor, MI; and the Research Division on Substance Abuse, Department of Psychiatry and Behavioral Neurosciences (MKG, CRS, CEJ), Wayne State University, Detroit, MI.

Address correspondence to: Jon-Kar Zubieta, M.D., Ph.D., The University of Michigan, Neuroscience Building, 1103 E. Huron Street, Ann Arbor, MI 48104-1687.

Received September 8, 1999; revised February 21, 2000; accepted March 3, 2000. toxicity, treat overdoses) but a primary goal is to attenuate the subjective, behavioral, or physiological effects of the drug of abuse. Buprenorphine is a high affinity, mu opioid partial agonist, with kappa antagonist action (Cowan et al. 1977; Heel et al. 1979; Lewis et al. 1983). This compound is being evaluated as an alternative to methadone maintenance and detoxification in the treatment of opioid dependence (Bickel and Amass 1995). Buprenorphine's mu receptor $(\mu \mathrm{OR})$ agonist actions could reduce opiate craving and prevent withdrawal, thus improving compliance with treatment compared to conventional opiate receptor antagonists (e.g., naltrexone). At the same time, its partial efficacy and high affinity at $\mu \mathrm{OR}$ 's provide long lasting functional antagonism, making it an effective means of blocking the effects of abused opiates. This unique combination of 
pharmacological properties confers potential advantages, including enhanced safety over existing medications for treating opioid abuse (Lange et al. 1990).

Buprenorphine sublingual (SL) liquid has been shown to decrease heroin self-administration in singledose human laboratory studies (Mello and Mendelson 1980; Mello et al. 1981, 1982); the dose-dependency of its effects on reinforcement has been less well characterized. In a clinical study, Johnson et al. (1995) compared the short-term efficacy of placebo, 2 and $8 \mathrm{mg} /$ day buprenorphine in a parallel group, randomized design during a two-week initial maintenance period. In this study, active doses were more effective than placebo in decreasing heroin use, however, there were no differences in therapeutic efficacy between 2 and $8 \mathrm{mg}$. Schottenfeld et al. (1993) used a within-subject study design in which heroin-dependent outpatients received ascending/descending maintenance doses of buprenorphine ranging from 2 to $16 \mathrm{mg} /$ day. Sixteen milligrams produced significant decreases in opioid-positive urine samples, relative to lower doses. Thus, available data suggest that, relative to placebo, buprenorphine doses ranging from 2 to $8 \mathrm{mg}$ are equally capable of decreasing opioid use, whereas doses of $16 \mathrm{mg}$ have greater efficacy. This may suggest that the effect of buprenorphine in decreasing opiate self-administration may not be dose-dependent, at least in lower dose ranges. In fact, in a recently completed laboratory study in heroindependent volunteers, maintenance doses of 2,4 , and 8 $\mathrm{mg}$ buprenorphine showed equal efficacy in decreasing the reinforcing effects of hydromorphone (Greenwald et al. 1999).

On the other hand, laboratory studies have demonstrated that SL buprenorphine blocks many of the subjective effects of hydromorphone, a full mu opioid agonist, in a dose-dependent manner. For instance, Bickel et al. (1988) showed that maintenance on buprenorphine $(2,4,8,16 \mathrm{mg})$ produced dose-related decreases in subjective effects to cumulative hydromorphone (0, 6, $18 \mathrm{mg}$ subcutaneous) challenges. Rosen et al. (1994) also found that maintenance on buprenorphine $12 \mathrm{mg}$ (relative to 2 and $6 \mathrm{mg}$ ) significantly blocked the subjective effects produced by hydromorphone relative to maintenance on 2 and $6 \mathrm{mg}$.

A central principle of pharmacotherapy of opiate dependence is that the clinical efficacy of medications is directly related to their occupancy of brain opioid receptors. Positron emission tomography (PET) and radiotracers that label opioid receptors have become available to examine this hypothesis. A single preliminary report has shown that participants who were stabilized on methadone (30-90 mg/day) and abstinent from heroin had $22-35 \%$ lower opioid receptor availability than healthy controls, 22 hours after the last dose. These data suggest that relatively low degrees of occupancy are needed to induce clinically significant ef- fects (Kling et al. 1997). However, this study was conducted utilizing $\left[{ }^{18} \mathrm{~F}\right]$ cyclofoxy, which is a non-selective $\mu \mathrm{OR}$ and kappa receptor marker (Carson et al. 1993), and therefore the receptor availability measure calculated does not refer to one but two receptor sites. Since methadone has much higher affinity for mu than for kappa receptor sites (Kristensen et al. 1995), the use of a non-selective radiotracer would underestimate changes in $\mu \mathrm{OR}$ availability. Also, the study assumed that healthy subjects and methadone-maintained participants had similar regional $\mu \mathrm{OR}$ binding concentrations, which may not be the case. Similar studies have not been conducted with partial opioid agonists, such as buprenorphine, or with receptor-selective radiotracers.

In this study we present preliminary data on the in vivo availability of $\mu \mathrm{OR}$ 's after treatment with SL buprenorphine $2 \mathrm{mg}, 16 \mathrm{mg}$, and after detoxification on 0 $\mathrm{mg}$, under double-blind conditions. Mu opioid receptor binding was examined in three otherwise healthy opioiddependent volunteers and in age-matched controls with PET and the selective $\mu \mathrm{OR}$ radiotracer $\left[{ }^{11} \mathrm{C}\right]$ carfentanil.

\section{METHODS}

\section{Participant Recruiting and Selection}

The Institutional Review Boards of Wayne State University and the University of Michigan approved all procedures and experimental protocols. Three opioiddependent volunteers and three age-matched nondependent healthy volunteers between the ages of 20 and 50 were recruited through newspaper advertisements. All volunteers provided written informed consent and were paid for their participation. Opioiddependent volunteers were not seeking treatment and willing to participate in a short-term study involving buprenorphine maintenance and detoxification.

A structured interview (SCID-IV) (First et al. 1996) was administered by an experienced, masters' level psychologist, to all volunteers (SCID-IV patient version in the case of heroin-dependent volunteers, SCID-IV non-patient version for healthy control subjects) to rule out the presence of psychiatric illnesses and diagnose opioid dependency. Severity of opioid dependence was determined using the Addiction Severity Index (McLellan et al. 1985a,b). Volunteers were included who were otherwise healthy, and had no present or past history of psychiatric illnesses, except for nicotine dependence, acute medical or neurological illnesses. Volunteers who met DSM-IV criteria for antisocial personality disorder were also excluded.

\section{Drug Preparation}

Opioid-dependent participants were maintained on ascending, then descending sublingual (SL) buprenor- 
phine (BUP) doses over a six-week period. The liquid formulation (1 ml ped-pods; National Institute on Drug Abuse) was used to administer BUP. These contained BUP concentrations of $2 \mathrm{mg} / \mathrm{ml}, 4 \mathrm{mg} / \mathrm{ml}$, and $8 \mathrm{mg} /$ $\mathrm{ml}$ in $30 \%$ ethanol vehicle. Liquid from the ped-pods was transferred to $1 \mathrm{ml}$ syringes (without needles). To maintain double-blind conditions, two syringes per day were used to deliver the medication under the tongue. The $1 \mathrm{mg}$ doses (detoxification phase; see below) were prepared by mixing $1 \mathrm{mg}$ of BUP hydrochloride powder (National Institute on Drug Abuse) with vehicle, and placebo doses/syringes were prepared using only vehicle.

\section{Procedures}

Drug Administration. Dependent volunteers received BUP doses in the following order: $2 \mathrm{mg}$ on days 1-10 (followed by a PET scan on day 10); $4 \mathrm{mg}$ on days 11 and 12; $8 \mathrm{mg}$ on days 13 and $14 ; 16 \mathrm{mg}$ on days $15-24$ (followed by a PET scan on day 24); $8 \mathrm{mg}$ on days 25 and 26; $4 \mathrm{mg}$ on days 27 and 28; $2 \mathrm{mg}$ on days 29 and 30; $1 \mathrm{mg}$ on days 31 and 32; and $0 \mathrm{mg}$ (placebo) on days 3341 (followed by a PET scan on day 41). Administration of BUP took place daily, at approximately the same time. Buprenorphine doses were held under the tongue for $5 \mathrm{~min}$ in the presence of a research assistant, after which the volunteer was instructed to swallow any remaining liquid. BUP administration took place on an outpatient basis until four days prior to each PET scanning session, when dependent participants were admitted into an inpatient unit.

Clinical Measures. Observed urine samples for toxicology testing were obtained twice a week during the outpatient period, and daily during the residential stay. Semiquantitative analyses of these urine samples were performed using fluorescence polarization immunoassay (FPIA; Abbott ADx instrument and standard reagents). These were analyzed for levels of opiates, methadone, cocaine, benzodiazepines, and barbiturates. Opiate drug levels were below the standard cutoff value $(200 \mathrm{ng} / \mathrm{ml})$ and all other drug levels were negative on the day of each PET scan.

Vital signs (respiration rate, oral temperature, oxygen saturation, heart rate, and non-invasive blood pressure) were measured each inpatient day, before and periodically after daily buprenorphine administration. Opiate symptoms and heroin craving were rated for the three days prior to each PET scan in the inpatient research unit. Opiate agonist and withdrawal symptoms were assessed using a 32-item questionnaire (see Schuster et al. 1995). Sixteen items are related to agonist symptoms (nodding, dry mouth, turning of stomach, skin itchy, relaxed, coasting, pleasant sick, drive/energy, nervous, good mood, high, sleepy, drunken, soap- box/talkative, rush, friendly) and 16 items are related to withdrawal symptoms (yawning, restless, watery eyes, runny nose, sick to stomach, irritable, tense/jittery, chills/gooseflesh, sweating, hot or cold feelings, abdominal cramps, backache, skin clammy/damp, muscle cramps, painful joints, heavy/sluggish feeling). Each item was scored on a scale ranging from 0 (not at all) to 4 (extremely). Drug craving was assessed using the 34-item score from the Heroin Craving Questionnaire (HCQ) developed by Tiffany (see Schuster et al. 1995 for a description).

PET Scanning Procedures. Three PET scans were obtained in opioid-dependent participants starting $4 \mathrm{hrs}$ after the last administration of BUP $2 \mathrm{mg}$, BUP $16 \mathrm{mg}$, and placebo (BUP $0 \mathrm{mg}$ ), under double-blind conditions. A single PET scan was obtained in non-dependent participants. All volunteers refrained from smoking, caffeine and food intake for three hours prior to scanning. PET scans were acquired with a Siemens ECAT EXACT-47 scanner in 3-D mode (intrinsic FWHM resolution $\approx 6 \mathrm{~mm}$ in-plane and $5 \mathrm{~mm}$ in the $z$ axis), with septa retracted. Participants were positioned in the PET scanner gantry using the orbito-meatal line as reference line, and one intravenous (antecubital) line was placed. A light forehead restraint was used to eliminate intrascan movement. $\left[{ }^{11} \mathrm{C}\right]$ carfentanil was synthesized at high specific activity $(>1000 \mathrm{Ci} / \mathrm{mmol})$ by the reaction of ${ }^{11} \mathrm{C}$-methyliodide and a non-methyl precursor as previously described (Dannals et al. 1985), with minor modifications to improve its synthetic yield.

Approximately $15 \mathrm{mCi}(555 \mathrm{MBq})$ were administered to each subject per PET scan, with a maximum mass injected of $0.05 \mu \mathrm{g} / \mathrm{kg}$ per study. This ensured that the compound was administered in tracer quantities, i.e., subpharmacological doses. Fifty-five percent of the $\left[{ }^{11} \mathrm{C}\right]$ carfentanil dose was administered as a bolus, and the remainder as a continuous infusion, using a computer-controlled automated pump to achieve steadystate tracer levels. Sixteen sets of scans were acquired over $70 \mathrm{~min}$ with an increasing duration (30 sec up to 10 $\mathrm{min})$. Time points were decay-corrected by a calculated method and reconstructed using Hanning 0.5 filtered back-projection, in a $24 \times 24 \mathrm{~cm}$ field of view and a $128 \times$ 128 pixel matrix, with scatter correction. Attenuation correction was performed through a 10-min transmission scan $\left({ }^{68} \mathrm{Ge}\right.$ source) obtained immediately prior to the PET study. Dynamic images were then co-registered using automated computer routines (Minoshima et al. 1992).

Image data were transformed, on a pixel-by-pixel basis, into two sets of parametric maps: 1 ) a tracer transport measure ( $\mathrm{K}_{1}$ ratio), which is proportional to cerebral blood flow (Tracer Transport $=$ Blood Flow $\times$ Extraction); and 2) a receptor-related measure. To avoid repeated arterial blood sampling, the tracer transport 
and binding measures were calculated using a modified Logan graphical analysis (Logan et al. 1996), with the occipital cortex (an area devoid of $\mu \mathrm{OR}$ 's) (Frost et al. 1989) as input function (distribution volume ratio, DVR). The Logan plot becomes sufficiently linear by 5 min after the start of radiotracer administration with a slope proportional to the $(\mathrm{Bmax} / \mathrm{Kd})+1$ for this receptor site (Koeppe 1999), where Bmax/ Kd is often referred to as the "binding potential" (Mintun et al. 1984).

$\mathrm{K}_{1}$ images were then aligned to the intercommisural line and non-linear warped to stereotactic coordinates, as previously described (Minoshima et al. 1993, 1994). The transformation matrix was then applied to the coregistered DVR images. $K_{1}$ and DVR images were analyzed using a template of regions-of-interest (ROIs) placed on various brain structures following Talairach and Tournoux (1988) stereotactic coordinates. ROI's were cubic volumes of $6.75 \mathrm{~mm}$ each side positioned first on the $K_{1}$ images and then applied to the DVR binding maps. ROI's were placed bilaterally in all regions, at three separate levels, following Brodmann definitions, and averaged within each region. Since no lateralization of the effects of buprenorphine was expected, right and left-sided ROI's were again averaged to yield a single regional value.

$\mathrm{Mu}$ opioid receptor availability data are expressed as the mean \pm 1 s.d. for the DVR minus 1 of each region (referred to as binding potential). In some instances, the percent coefficient of variation (\%COV) is also utilized to illustrate variability across participants $[\% \mathrm{COV}=$ $($ s.d. $\times 100) /$ mean]. Dose-dependent changes in heroinwithdrawal symptoms, craving scores and regional $\mu \mathrm{OR}$ availaibility were examined with independent, one-way repeated measures ANOVA for each region. Baseline receptor binding potential at BUP $0 \mathrm{mg}$ was compared to that of control participants using independent $\mathrm{F}$ tests for each region. The minimum level of significance was set at $p<.05$.

\section{RESULTS}

\section{Participant Characteristics and Clinical Measures}

Demographic information and drug use of the two groups of participants are shown in Table 1. Mean ( \pm s.d.) opioid withdrawal scores in the opioid-dependent participants were lowest when they were maintained on the higher BUP dose, $16 \mathrm{mg}(1.7 \pm 1.8)$, intermediate at the $2 \mathrm{mg}$ dose $(3.2 \pm 4.0)$, and highest under placebo conditions (BUP $0 \mathrm{mg}, 17.3 \pm 8.3)(\mathrm{F}(2,4)=7.08, p<$ $.05)$. Similar effects were noted for heroin-craving scores (BUP $16 \mathrm{mg}, 97 \pm 27$; BUP $2 \mathrm{mg}, 107 \pm 21$; and BUP $0 \mathrm{mg}, 143 \pm 14)(\mathrm{F}(2,4)=11.30, p<.03)$. Opiate agonist effects were not significantly different across BUP doses $(p>.05)$. There were no clinically significant changes in vital signs related to BUP dose, although ox- ygen saturation showed a dose-related trend (BUP 16 $\mathrm{mg}, 94.9 \pm 1.3 \%$; BUP $2 \mathrm{mg}$, $95.6 \pm 1.1 \%$; BUP 0 mg, $97.0 \pm$ $2.0 \%)$.

\section{Mu Opioid Receptor Availability After Buprenorphine Administration}

A summary of the data for the $\mu \mathrm{OR}$ binding measure is presented in Table 2. Compared to the placebo (BUP 0) condition, BUP $2 \mathrm{mg}$ reduced regional $\mu \mathrm{OR}$ availability in the range of 36 to $50 \%$. Administration of BUP $16 \mathrm{mg}$ was associated with reductions in $\mu \mathrm{OR}$ availability in the range of 79 to $95 \%$ (Figure 1). Significant dosedependency was demonstrated for all the brain regions examined, with the exception of the inferofrontal cortex (Brodmann area 11) that only reached trend levels $(p=$ .06) (Table 2).

Individual subject variability in regional $\mu \mathrm{OR}$ availability at the two BUP doses studied depended both of the regions examined (higher variability was observed, as expected, in areas with low receptor concentration, i.e., the cerebellum, but also in some other regions with relatively high $\mu \mathrm{OR}$ binding) and the BUP dose. For example, and at the BUP $2 \mathrm{mg}$ dose, \%COVs of the proportion of change were as low as 12 and $15 \%$ in the anterior cingulate Brodmann areas 32 and 25, respectively, to as high as 35 and $41 \%$ in the inferofrontal cortex (prefrontal cortex BA 11) and amygdala, respectively. Less inter-individual variability was noted for the BUP $16 \mathrm{mg}$ condition, with \%COVs at or below $10 \%$ for regions with higher $\mu \mathrm{OR}$ concentrations, and up to $15 \%$ for low $\mu \mathrm{OR}$ binding regions, such as the cerebellum.

\section{Differences in Mu Opioid Receptor Availability Between Controls and Heroin-Dependent Volunteers During the Placebo Condition}

The in vivo availability of $\mu \mathrm{OR}$ 's was also compared between non-dependent volunteers and heroin-depen-

Table 1. Demographic Information of Participants

\begin{tabular}{|c|c|c|}
\hline & Heroin-Dependent & Controls \\
\hline Age (years) & $41 \pm 2$ & $42 \pm 2$ \\
\hline Ethnicity & $2 \mathrm{AA}, 1 \mathrm{H}$ & $2 \mathrm{C}, 1 \mathrm{~A}$ \\
\hline Education (years) & $12 \pm 1$ & $15 \pm 3$ \\
\hline \multicolumn{3}{|c|}{ Mean years heroin use/ } \\
\hline \$ spent/week & $18 / \$ 175$ & $\mathrm{~N} / \mathrm{A}$ \\
\hline$\%$ cigarette smokers & 100 & 0 \\
\hline $\begin{array}{l}\% \text { regular alcohol use } \\
\text { in past } 30 \text { days }\end{array}$ & $\%$ regular alcohol use & 0 \\
\hline $\begin{array}{l}\% \text { marihuana use in } \\
\text { past } 30 \text { days }\end{array}$ & 100 & 0 \\
\hline \multicolumn{3}{|l|}{$\%$ cocaine use in past } \\
\hline 30 days & 33 & 0 \\
\hline
\end{tabular}

$\mathrm{AA}=$ African American; $\mathrm{H}=$ Hispanic $\mathrm{C}=$ Caucasian $; \mathrm{A}=$ Asian 
Table 2. Dose-dependent changes in Mu Opioid Receptor Availability by Sublingual Buprenorphine in Three Heroin-Dependent Volunteers

\begin{tabular}{|c|c|c|c|c|c|c|c|}
\hline \multirow[b]{2}{*}{ Region } & \multirow{2}{*}{$\frac{\text { BUP 0 mg }}{\text { BP }}$} & \multicolumn{2}{|c|}{ BUP 2 mg } & \multicolumn{2}{|c|}{ BUP 16 mg } & \multirow[b]{2}{*}{ F-value } & \multirow[b]{2}{*}{$p$} \\
\hline & & BP & ( $\% \Delta$ from BUP 0) & BP & $(\% \Delta$ from BUP 0) & & \\
\hline Prefrontal cortex (BA 10) & $1.38 \pm 0.40$ & $0.76 \pm 0.33$ & $(-47 \pm 9)$ & $0.23 \pm 0.15$ & $(-85 \pm 9)$ & 42.0 & $.002 *$ \\
\hline Prefrontal cortex (BA 11) & $1.62 \pm 1.00$ & $0.79 \pm 0.30$ & $(-46 \pm 16)$ & $0.30 \pm 0.20$ & $(-82 \pm 7)$ & 6.2 & .06 \\
\hline Anterior cingulate (BA 32) & $1.67 \pm 0.56$ & $0.97 \pm 0.39$ & $(-43 \pm 5)$ & $0.23 \pm 0.13$ & $(-86 \pm 5)$ & 25.2 & $.005^{*}$ \\
\hline Anterior cingulate (BA 25) & $1.65 \pm 0.86$ & $0.85 \pm 0.33$ & $(-46 \pm 7)$ & $0.30 \pm 0.23$ & $(-84 \pm 8)$ & 11.9 & $.02^{*}$ \\
\hline Anterior temporal cortex & $1.55 \pm 0.54$ & $0.82 \pm 0.41$ & $(-49 \pm 8)$ & $0.24 \pm 0.13$ & $(-85 \pm 5)$ & 28.4 & $.004^{*}$ \\
\hline Caudate nucleus (dorsal) & $2.29 \pm 0.30$ & $1.32 \pm 0.32$ & $(-42 \pm 12)$ & $0.34 \pm 0.17$ & $(-85 \pm 1)$ & 61.5 & $.001^{*}$ \\
\hline Caudate nucleus (ventral) & $2.79 \pm 1.00$ & $1.43 \pm 0.60$ & $(-50 \pm 6)$ & $0.49 \pm 0.24$ & $(-82 \pm 6)$ & 19.9 & $.008^{*}$ \\
\hline Putamen & $1.82 \pm 0.26$ & $0.99 \pm 0.23$ & $(-46 \pm 7)$ & $0.32 \pm 0.02$ & $(-82 \pm 2)$ & 73.4 & $.0007^{*}$ \\
\hline Thalamus & $2.70 \pm 0.55$ & $1.57 \pm 0.40$ & $(-42 \pm 9)$ & $0.56 \pm 0.17$ & $(-79 \pm 8)$ & 32.4 & $.003^{*}$ \\
\hline Hypothalamus & $1.47 \pm 0.76$ & $0.71 \pm 0.30$ & $(-50 \pm 9)$ & $0.07 \pm 0.21$ & $(-95 \pm 14)$ & 8.7 & $.03^{*}$ \\
\hline Amygdala & $1.82 \pm 0.79$ & $1.13 \pm 0.49$ & $(-37 \pm 15)$ & $0.23 \pm 0.06$ & $(-86 \pm 3)$ & 13.3 & $.02 *$ \\
\hline Midbrain & $1.01 \pm 0.22$ & $0.55 \pm 0.22$ & $(-47 \pm 11)$ & $0.15 \pm 0.09$ & $(-85 \pm 11)$ & 27.0 & $.005^{*}$ \\
\hline Cerebellum & $1.09 \pm 0.40$ & $0.72 \pm 0.43$ & $(-36 \pm 21)$ & $0.23 \pm 0.18$ & $(-82 \pm 13)$ & 16.3 & $.01^{*}$ \\
\hline
\end{tabular}

Data represents the mean \pm 1 s.d. of $\mu \mathrm{OR}$ binding potential $(\mathrm{Bmax} / \mathrm{Kd})$ in three heroin dependent volunteers studied during the sublingual administration of buprenorphine at $0 \mathrm{mg}$ (placebo), $2 \mathrm{mg}$, and $16 \mathrm{mg}$. The percent change respect to the placebo condition is indicated in parenthesis (\% $\Delta$ from BUP 0). Dose-dependency of receptor availability was examined for each individual region with one-way repeated measures ANOVA $(\mathrm{df}=$ $2,4)$. Their corresponding F-values and level of significance achieved $(p)$ are shown in the right columns. BUP $=$ buprenorphine; BP $=$ binding potential.

*Statistically significant at $p<.05$.

dent volunteers after withdrawal of BUP (placebo condition) (Figure 1). Higher regional $\mu \mathrm{OR}$ binding potential was generally observed in the heroin-dependent volunteers, which reached statistical significance in the inferofrontal cortex (BA 11) and anterior cingulate regions (BA 25 and 32), even with the small sample studied. Trend differences were obtained in the prefrontal cortex (BA 10) and ventral caudate (including the nucleus accumbens) regions (Table 3 ).

When the differences in $\mu \mathrm{OR}$ binding were calculated as the percentage difference between the mean of the non-dependent volunteers and the individual values obtained in the heroin-dependent men, a high degree of regional and inter-individual variability was observed. This is reflected by the high standard deviation obtained for these values (Table 3). In the case of the brain regions in which significant group differences were noted, individual differences in binding ranged from $-20 \%$ to $+63 \%$ in the pregenual anterior cingulate (BA 32), $-7 \%$ to $+164 \%$ in the subgenual anterior cingulate (BA 25), to as high as $-13 \%$ to $+200 \%$ in the inferofrontal cortex (BA 11).

\section{DISCUSSION}

This study describes regional in vivo $\mu \mathrm{OR}$ binding data obtained in a small number of heroin-dependent volunteers during maintenance on buprenorphine, a $\mu \mathrm{OR}$ partial agonist, and placebo, compared with an equal number of age-matched non-dependent drug-free volunteers. Two main findings are reported: First, bu- prenorphine maintenance reduced $\mu \mathrm{OR}$ availability, as measured with $\left[{ }^{11} \mathrm{C}\right]$ carfentanil and PET within subjects, in a dose-related manner (in the range of 36 to $50 \%$ for the $2 \mathrm{mg}$ sublingual dose, and in the range of 79 to $95 \%$ for the $16 \mathrm{mg}$ dose, depending on the brain regions). Second, $\mu \mathrm{OR}$ binding potential $(\mathrm{Bmax} / \mathrm{Kd})$ in heroin-dependent volunteers studied after buprenorphine treatment and two weeks of placebo administration was highly variable between subjects, and significantly increased in paralimbic brain regions, compared to control values in non-dependent volunteers.

The reductions in $\mu \mathrm{OR}$ availability achieved with buprenorphine, as compared to the placebo condition, were higher that those reported using a full agonist (methadone), which ranged between 22 and 35\% for fully therapeutic doses (Kling et al. 1997). The differences in the proportion of receptors occupied by therapeutic agents for heroin dependence between the current data and the report by Kling et al. (1997) may be due to various factors. First, it is possible that a larger proportion of receptor occupancy may be required for a partial agonist to induce clinically significant effects. Buprenorphine has been shown to be clinically effective at or above $8 \mathrm{mg}$ (Bickel and Amass 1995; Schottenfeld et al. 1993). However, technical factors may also play a role. The data from Kling et al. (1997) were obtained with a non-selective radiotracer, $\left[{ }^{11} \mathrm{C}\right]$ cyclofoxy, which binds with high affinity to both $\mu \mathrm{OR}$ and kappa receptor subtypes. Differences in receptor availability during methadone maintenance would be underestimated because methadone has much higher affinity for the $\mu \mathrm{OR}$ than for kappa sites (Kristensen et al. 1995), therefore 


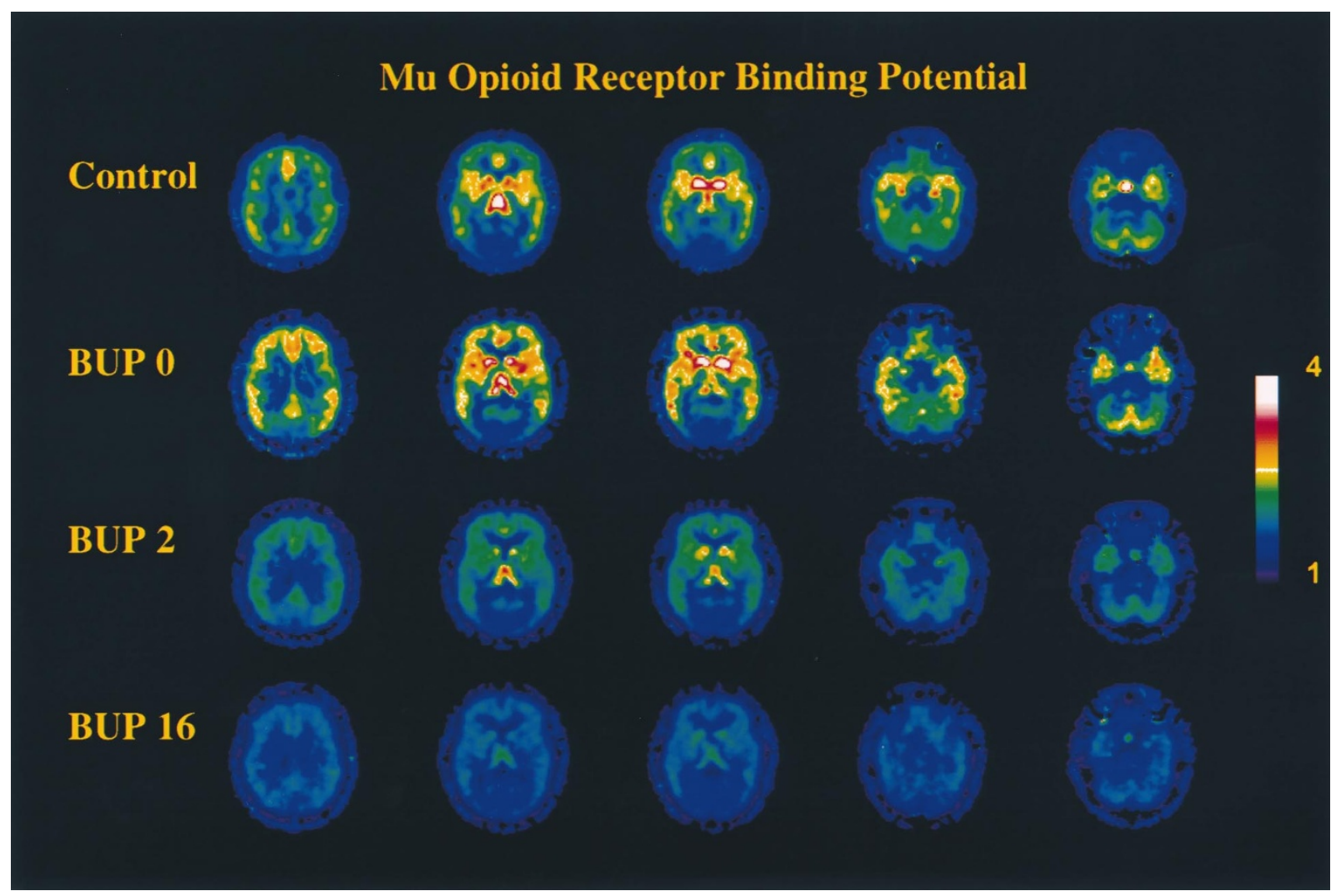

Figure 1. Parametric images of binding potential $(B m a x / K d)$ (extracted from Logan plot slopes with occipital cortex as input function) in two representative subjects: a non-dependent control (Control), and a matched heroin-dependent volunteer. The latter is shown under placebo conditions (BUP 0), during treatment with $2 \mathrm{mg}$ (BUP 2) and $16 \mathrm{mg}$ (BUP 16) sublingual liquid. Images are scaled so the occipital cortex binding potential, an area devoid of mu opioid receptors, is equal to 1. Five anatomical levels are shown, from superior (left) to inferior (right). The pseudocolor scale utilized is presented on the right side, using a color range depicting binding potential values from 1 to 4 .

occupying only one of two receptor sites labeled. Also, in the present report we examined $\mu \mathrm{OR}$ availability within participants at different buprenorphine doses, whereas in that of Kling et al. (1997), participants maintained on widely varying doses were examined once and compared to an untreated control group. Because we observed that heroin-dependent volunteers had generally higher levels of $\mu \mathrm{OR}$ availability during the placebo condition than non-dependent participants, the calculation of receptor binding differences between detoxified volunteers and a control group would underestimate the receptor occupancy by methadone.

Another aspect of these dose-dependent changes in in vivo $\mu \mathrm{OR}$ binding after buprenorphine administration is the relatively high variability in the reductions observed at the lower dose studied ( $2 \mathrm{mg}$ ). While the intrasubject variation in $\mu \mathrm{OR}$ binding at the $16 \mathrm{mg}$ dose was small, and typically within $10 \%$ of the mean values $(\% \mathrm{COV})$, a higher regional variability was noted at the $2 \mathrm{mg}$ dose. Specifically, the inferofrontal cortex (Brodmann area 11) and the amygdala registered the highest interindividual variability at this dose, with the indi- vidual binding values ranging from 31 to $61 \%$ and from 20 to $52 \%$ below the placebo condition for those two regions, respectively. These regional differences may be due to technical factors (i.e., partial volume averaging in small brain areas), local differences in the proportion of endogenous ligand or regional differences in receptor number and/or affinity. However, the examination of possible regional differences in $\mu \mathrm{OR}$ occupancy by low buprenorphine doses will require both a larger population of volunteers and additional in vitro studies to fully determine its presence and implications.

Even with the very small sample studied in this preliminary report, significant differences in $\mu O R$ availability in vivo were detected between non-dependent controls and heroin-dependent volunteers during the placebo condition. While generally increased in most brain regions of heroin-dependent volunteers, $\mu \mathrm{OR}$ binding potential was statistically different between groups in the inferior prefrontal cortex (Brodmann area 11), anterior cingulate (Brodmann areas 32 and 25), and reached trend significance levels in the prefrontal cortex area 10 and ventral caudate/nucleus accumbens region. 
Table 3. Summary of Binding Data in Three Healthy Non-Dependent Volunteers and Regional Differences with Three Heroin-Dependent Volunteers Studied During Placebo Administration

\begin{tabular}{|c|c|c|c|c|}
\hline Region & $\begin{array}{l}\text { Controls } \\
\text { BP }\end{array}$ & $\begin{array}{c}\text { BUP 0 mg } \\
(\% \Delta \text { from Controls) }\end{array}$ & F-Value & $p$ \\
\hline Prefrontal cortex (BA 10) & $0.94 \pm 0.07$ & $(48 \pm 43)$ & 29.9 & .06 \\
\hline Prefrontal cortex (BA 11) & $0.91 \pm 0.04$ & $(78 \pm 110)$ & 500.7 & $.004^{*}$ \\
\hline Anterior cingulate (BA 32) & $1.29 \pm 0.09$ & $(29 \pm 43)$ & 36.9 & $.05^{*}$ \\
\hline Anterior cingulate (BA 25) & $1.02 \pm 0.06$ & $(62 \pm 84)$ & 234.4 & $.008^{*}$ \\
\hline Anterior temporal cortex & $1.18 \pm 0.15$ & $(31 \pm 46)$ & 13.3 & .13 \\
\hline Caudate nucleus (dorsal) & $2.03 \pm 0.13$ & $(14 \pm 15)$ & 5.0 & .33 \\
\hline Caudate nucleus (ventral) & $2.01 \pm 0.19$ & $(39 \pm 50)$ & 27.7 & .07 \\
\hline Putamen & $1.53 \pm 0.14$ & $(19 \pm 17)$ & 3.3 & .46 \\
\hline Thalamus & $2.34 \pm 0.43$ & $(15 \pm 24)$ & 1.6 & .76 \\
\hline Hypothalamus & $1.23 \pm 0.40$ & $(20 \pm 62)$ & 3.6 & .43 \\
\hline Amygdala & $1.51 \pm 0.37$ & $(21 \pm 52)$ & 4.5 & .36 \\
\hline Midbrain & $0.93 \pm 0.13$ & $(10 \pm 23)$ & 2.6 & .56 \\
\hline Cerebellum & $0.79 \pm 0.27$ & $(38 \pm 51)$ & 2.2 & .62 \\
\hline
\end{tabular}

Data represents the mean \pm 1 s.d. of $\mu \mathrm{OR}$ availability (binding potential, Bmax/Kd) in three healthy non-dependent volunteers and, in parenthesis, the percent difference $(\% \Delta)$ with three matched heroin-dependent volunteers studied during placebo administration (buprenorphine $0 \mathrm{mg}$ ). This value was calculated as the \% difference between the regional mean of the controls and the individual regional value for the heroin-dependent volunteers.

$\mathrm{BUP}=$ buprenorphine; $\mathrm{BP}=$ binding potential.

*Statistically significant difference between $\mu \mathrm{OR}$ binding potential of controls and heroin-dependent volunteers, F-test, $\mathrm{df}=2, p \leqslant .05$.

These were unexpected results, since experimental animal data have shown that the chronic administration of buprenorphine is associated with a down-regulation of rat forebrain $\mu \mathrm{OR}$ (and concomitant up-regulation of kappa receptors) without changes in affinity (Belcheva et al. 1993). This may also be the case with morphine (Ulibarri et al. 1987; Tempel et al. 1988), albeit upregulatory changes in $\mu \mathrm{OR}$ binding have been described after chronic treatment with heroin (Bolger et al. 1988). However, it should be noted that our measures were obtained after treatment with ascending, then descending doses of buprenorphine, and two weeks of placebo administration. Therefore, these increases may represent a neurobiological correlate of opioid (or less likely, buprenorphine) withdrawal and upregulatory changes in $\mu \mathrm{OR}$ 's or its coupling mechanisms. Confirmation of the differences in regional binding between groups and the variability of the data between heroin-dependent volunteers exceeding that of control subjects will require a larger sample size.

If these findings are confirmed, they are likely to be of importance for the study of $\mu \mathrm{OR}$ involvement in heroinwithdrawal. Increases in $\mu \mathrm{OR}$ binding have been associated with craving scores in cocaine-dependent volunteers undergoing cocaine withdrawal (Zubieta et al. 1996). In a larger sample, it would be of interest to evaluate the relationship between $\mu \mathrm{OR}$ binding potential in these regions and measures of withdrawal or craving for opiates. In addition, the high level of interindividual variability in the degree of receptor upregulation observed in heroin-dependent volunteers may reflect prior patterns of heroin or other substance use, pre-existing individual differences (Zubieta et al. 1999), or clinical profiles (i.e., severity of craving). This is an important issue which would need to be explored in larger populations, preferably in a longitudinal, prospective design, specially since it could possibly be associated with the predisposition of individual subjects to use or relapse in the use of heroin or other drugs of abuse. The contribution of other substances of abuse (i.e., nicotine, alcohol, marijuana) to changes in $\mu \mathrm{OR}$ binding will also require additional control groups.

In summary, these preliminary data suggest that buprenorphine induces a dose-related reduction in $\mu \mathrm{OR}$ availability, reaching a high level $(\approx 90 \%)$ of receptor occupancy at a dose $(16 \mathrm{mg})$ that has been shown to be clinically effective in treatment studies. Heroin-dependent volunteers recently detoxified also show increases in $\mu \mathrm{OR}$ binding potential relative to controls that are both regionally and individually variable. Future studies will examine the clinical and symptomatic implications of this variability.

\section{ACKNOWLEDGMENTS}

This research was supported by USPHS Grant DA000254 from the National Institute on Drug Abuse and a research grant (Joe Young, Sr.) from the State of Michigan. The authors are grateful to Richard Berchou for preparation of liquid buprenorphine doses; Karen Downey for clinical diagnosis; John Hopper for medical oversight; Joy Chudyzinski for data management; Ken Bates for recruiting research volunteers; Ja'Near 
Mathis for urine toxicology testing; staff of the Neuropsychiatric Research Unit at Wayne State University for clinical data collection; and the technologists at the University of Michigan PET Center for image acquisition and reconstruction.

\section{REFERENCES}

Belcheva MM, Barg J, McHale RJ, Dawn S, Ho MT, Ignatova E, Coscia CJ (1993): Differential down- and up-regulation of rat brain opioid receptor types and subtypes by buprenorphine. Mol Pharmacol 44:173-179

Bickel WK, Amass L (1995): Buprenorphine treatment of opioid dependence: A review. Exp Clin Psychopharmacol 3:477-489

Bickel WK, Stitzer ML, Bigelow GE, Liebson IA, Jasinski DR, Johnson RE (1988): Buprenorphine: Dose-related blockade of opioid challenge effects in opioid dependent humans. J Pharmacol Exp Ther 247:47-53

Bolger GT, Skolnick P, Rice KC, Weissman BA (1988): Differential regulation of mu-opiate receptors in heroin- and morphine-dependent rats. FEBS Lett 234:22-26

Carson RE, Channing MA, Blasberg RG, Dunn BB, Cohen RM, Rice KC, Herscovitch P (1993): Comparison of bolus and infusion methods for receptor quantification: Application to $\left[{ }^{18} \mathrm{~F}\right]$ cyclofoxy and positron emission tomography. J Cereb Blood Flow Metab 13:24-42

Cowan A, Lewis JW, Macfarlane IR (1977): Agonist and antagonist properties of buprenorphine: A new antinociceptive agent. Br J Pharmacol 60:537-545

Dannals RF, Ravert HT, Frost JJ, Wilson AA, Burns HD, Wagner HN Jr (1985): Radiosynthesis of an opiate receptor binding radiotracer: [11C]carfentanil. Int J Appl Radiat Isot 36:303-306

First MB, Spitzer RL, Gibbon M, Williams JBW (1996): Structured Clinical Interview for DSM-IV Axis DisordersPatient Edition (SCID-I/P, Version 2.0). New York, NY: Biometrics Research Dept., NY State Psychiatric Institute

Frost JJ, Douglass KH, Mayberg HS, Dannals RF, Links JM, Wilson AA, Ravert HT, Crozier WC, Wagner HN Jr (1989): Multicompartmental analysis of $\left[{ }^{11} \mathrm{C}\right]$ carfentanil binding to opiate receptors in humans measured by positron emission tomography. J Cereb Blood Flow Metab 9:398-409

Greenwald MK, Johanson CE, Schuster CR (1999): Opioid reinforcement in heroin-dependent volunteers during buprenorphine maintenance. Drug Alcohol Depend 56:191-203

Heel RC, Brogdon RN, Speight TM, Avery GS (1979): Buprenorphine: a review of its pharmacological properties and therapeutic efficacy. Drugs 17:81-110

Johnson RE, Eissenberg T, Stitzer ML, Strain EC, Liebson IA, Bigelow GE (1995): A placebo controlled clinical trial of buprenorphine as a treatment for opioid dependence. Drug Alcohol Depend 40:17-25

Kling M, Borg L, Zametkin A, Schluger J, Carson R, Matochik J, Maslansky R, Khuri R, Wells A, Lambert S, Kreuter J, Herscovitch P, Eckelman W, Rice K, Ho A, Kreek MJ (1997): Opioid receptor binding in methadone maintained former heroin addicts by PET imaging using $\left[{ }^{18} \mathrm{~F}\right]$ cyclofoxy. NIDA Res Monogr 174:120
Koeppe RA (1999): Data analysis for PET studies of neuroreceptor modulation. J Nucl Med 5:287P

Kristensen K, Christensen CB, Christrup LL (1995): The $\mathrm{mu1}$, mu2, delta, kappa opioid receptor binding profiles of methadone stereoisomers and morphine. Life Sci 56:PL45-PL50

Lange WR, Fudala PJ, Dax EM, Johnson RE (1990): Safety and side effects of buprenorphine in the clinical management of heroin addiction. Drug Alcohol Depend 26:19-28

Lewis JW, Rance MJ, Sanger DJ (1983): The pharmacology and abuse potential of buprenorphine: A new antagonist analgesic. In Mello NK (ed), Advances in Substance Abuse, Vol. 3. Greenwich, CT, JAI Press, pp 103-154

Logan J, Fowlr JS, Volkow ND, Wang G-J, Ding Y-S, Alexoff DL (1996): Distribution volume ratios without blood sampling from graphical analysis of PET data. J Cereb Blood Flow Metab 16:834-840

McLellan AT, Luborsky L, Cacciola J, Griffith J, Evans F, Barr HL, O'Brien CP (1985a): New data from the Addiction Severity Index. J Nerv Ment Dis 173:412-423

McLellan AT, Luborsky L, O'Brien CP (1985b): Improved diagnostic instrument for substance abuse patients: The Addiction Severity Index. J Nerv Ment Dis 168:26-33

Mello NK, Mendelson JH (1980): Buprenorphine suppresses heroin use by heroin addicts. Science 207:657-659

Mello NK, Mendelson JH, Kuehnle JC (1982): Buprenorphine effects on human heroin self-administration: An operant analysis. J Pharmacol Exp Ther 223:30-39

Mello NK, Mendelson JH, Kuehnle JC, Sellers MS (1981): Operant analysis of human heroin self-administration. J Pharmacol Exp Ther 216:45-54

Minoshima S, Berger KL, Lee KS, Mintun MA (1992): An automated method for rotational correction and centering of three-dimensional functional brain images. J Nucl Med 33:1579-1585

Minoshima S, Koeppe RA, Mintun MA, Berger KL, Taylor SF, Frey KA, Kuhl DE (1993): Automated detection of the intercommisural line for stereotactic localization of functional brain images. J Nucl Med 34:322-329

Minoshima S, Koeppe RA, Frey KA, Kuhl DE (1994): Anatomic standardization: linear scaling and nonlinear warping of functional brain images. J Nucl Med 35:1528-1537

Mintun MA, Raichle ME, Kilbourn MR, Wooten GF, Welch MJ (1984): A quantitative model for the in vivo assessment of drug binding sites with positron emission tomography. Ann Neurol 15:217-227

Rosen MI, Wallace EA, McMahon TJ, Pearsall HR, Woods SW, Price LH, Kosten TR (1994): Buprenorphine: Duration of blockade of effects of intramuscular hydromorphone. Drug Alcohol Depend 35:141-149

Schottenfeld RS, Pakes J, Ziedonis D, Kosten TR (1993): Buprenorphine: Dose-related effects on cocaine and opioid use in cocaine-abusing opioid-dependent humans. Biol Psychiatry 34:66-74

Schuster CR, Greenwald K, Johanson CE, Heishman SJ (1995): Measurement of drug craving during naloxoneprecipitated withdrawal in methadone maintained volunteers. Exp Clin Psychopharmacol 3:424-431 
Talairach J, Tournoux P (1988): Co-planar Stereotaxic Atlas of the Human Brain. New York, Georg Thieme Verlag

Tempel A, Habas J, Paredes W, Barr GA(1988): Morphineinduced downregulation of mu-opioid receptors in neonatal rat brain. Brain Res 469:129-133

Ulibarri I, Garcia-Sevilla JA, Ugedo L (1987): Modulation of brain alpha 2-adrenoceptor and mu-opioid receptor densities during morphine dependence and spontane- ous withdrawal in rats. Naunyn-Schmied Arch Pharmacol 336:530-537

Zubieta JK, Dannals, RF, Frost JJ (1999): Gender and age influences on human brain mu opioid receptor binding measured by PET. Am J Psychiatry 156:842-848

Zubieta JK, Gorelick DA, Stauffer R, Ravert HT, Dannals RF, Frost JJ (1996): Increased $m u$ opioid receptor availability in cocaine abuse and its association with cocaine craving. Nature Med 2:1225-1229 